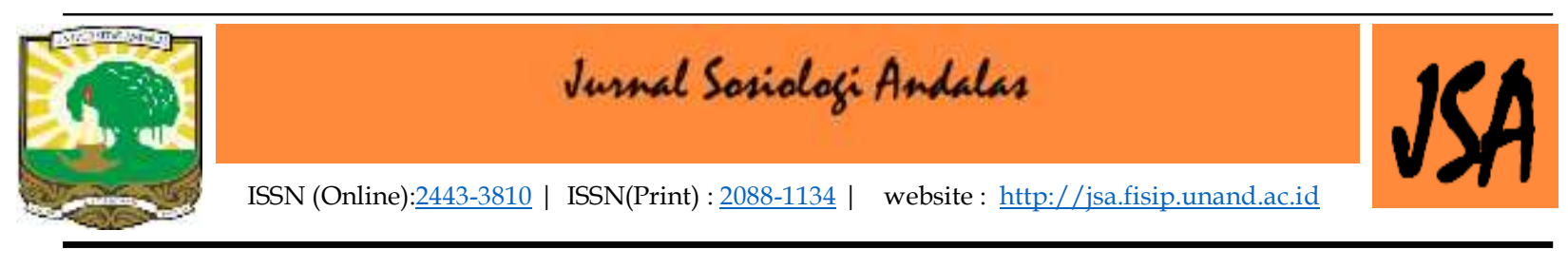

\title{
Model Resolusi Konflik Pemekaran Nagari
}

\author{
Fadil Haikal \\ Jurusan Sosiologi, FISIP Universitas Andalas \\ Email: fadiilhaikal03@gmail.com
}

\begin{abstract}
DPMN is the third party that helps to resolve the conflict between KAN Nagari Limo Koto and the so call Nagari preparatory government of Padang Laweh Selatan. In resolving the conflict, as a third party DPMN is able to resolve the conflict between the two parties. The objectives of this research are to describe the resolution of the conflict by both parties and by local governments and to describe the factors that enable DPMN to successfully resolve the conflicts. To achieve the research objectives, this study uses the Structuration Theory proposed by Anthony Giddens and qualitative research method. It was found that the conflict started in 2014 when Nagari Preparation Padang Laweh Selatan was in the process of expansion. At first the conflict was resolved by both parties by way of deliberations twice at the Koto VII sub-district office, but this was unsucessful. Then, after KAN Nagari Limo Koto sent a letter rejecting the expansion of the Nagari Preparation Padang Laweh Selatan to the Regent of Sijunjung, DPMN became the third party in resolving the conflict through conciliation. The conciliation process is carried out by: 1) forming a division team to resolve the conflict; 2) bringing together the two parties to the conflict; 3) collect data related to disputed ulayat lands; 4) trace the history of ulayat lands; 5) make the elite from KAN Nagari Limo Koto as partners in resolving conflicts; 6) make an agreement between the two parties through the Regional Regulation Ranperda; 7) disseminate the draft regional regulation to both parties. The factors that made it easier for DPMN to resolve the Conflict, namely: 1) making the regulations used in the process of dividing the preparatory village of South Padang Laweh as a reference; 2) actors DPMN and Elit Nagari Limo Koto understand that expansion aims to improve community welfare; 3) the conflict is not complicated.
\end{abstract}

Keywords: Villaged border conflict, conflict resolution, third party intervention, reconciliation.

\section{A.PENDAHULUAN}

Berbagai relasi antar manusia, antarkelompok, dan antarnegara tidak pernah bersih dari muatan kepentingan, penguasaan, permusuhuan, dan penindasan. Ini lah kodrat sosial dalam sejarah masyarakat manusia (Susan, 2010: 1). Oleh karena itu, konflik sudah menjadi bagian di dalam kehidupan masyarakat.

Melalui Permendagri no. 28 tahun 2006 tentang Pembentukan, Penghapusan, Penggabungan Desa, dan Perubahan status desa menjadi kelurahan, pemerintah memberi peluang pengadaan desa baru di luar desa yang ada. Menurut Permendagri tersebut tujuan dari pemekaran Nagari adalah untuk meningkatkan pelayanan publik guna mempercepat terwujudnya kesejahteraan masyarakat. Pembentukan desa baru, tentunya harus memenuhi syarat yang telah diteta Conflict resolution can be done by both parties or assisted by a third party.

Di Kabupaten Sijunjung terjadi konflik mengenai pembentukan desa baru yang menimbulkan konflik dengan nagari lain, bukan dengan nagari Induk . Dimana pada penyelesaian konfliknya pihak ketiga mampu menyelesaikan konflik 
tersebut, yaitu antara Nagari Persiapan Padang Laweh Selatan dengan KAN Nagari Limo Koto.

DPMN sebagai perwakilan Pemerintah Daerah Kabupaten Sijunjung terlibat dalam penyelesaian konflik tanah ulayat antara Nagari Persiapan Padang Laweh Selatan dengan Nagari Limo Koto dikarenakan Nagari Persiapan Padang Laweh Selatan sedang melakukan proses pemekaran nagari, dan menyerahkan penyelesaiannya ke Pemerintah Daerah. DPMN bertindak sebagai Instansi pemerintah yang mewadahi Pemekaran nagari, sehingga permasalahan tanah ulayat yang menjadi kendala pada proses pemekaran nagari, menjadi tanggung jawab DPMN. DPMN sebagai pihak ketiga dalam melakukan penyelesaian telah berhasil menyelesaikan konflik yang terjadi.

Terkait dengan itu, pertanyaan penelitiannya adalah bagaimana Pemerintah Daerah Kabupaten Sijunjung mampu menyelesaikan konflik antara Ninik Mamak Nagari Limo Koto dengan Pemerintah Nagari Persiapan Padang Laweh Selatan berkenaan dengan Tanah Ulayat? Serta bagaimana histori konflik tersebut.

\section{Tinjauan Pustaka}

\section{Definisi Konflik}

Afrizal menjelaskan bahwa dalam kehidupan sehari-hari, makna konflik hanya sebatas percekcokan dan perselisihan (Afrizal 2018: 4). Sedangkan Miall, Ramsbotham, dan Woodhouse menyatakan, konflik sebagai usaha untuk mewujudkan kepentingan yang bertentangan (Afrizal, 2018:5).

Penelitian ini menggunakan definisi konflik yang dinyatakan oleh Max Weber. "Max Weber mengartikan konflik sebagai suatu bentuk hubungan sosial yang didalamnya perbuatan sengaja dilakukan dan diarahkan kepada keberatan pihak lain, baik dengan menggunakan cara-cara damai atau cara-cara kekerasan. (Afrizal 2018:5).

Resolusi Konflik

Pruit dan Rubin mendefinisikan resolusi konflik sebagai strategi untuk mengakhiri kontroversi yang terjadi setelah kemandekan dan kesadaran masingmasing aktor konflik bahwa eskalasi bukanlah tindakan yang bijaksana sehingga kemudian terjadilah transisi, sehingga muncul cara-cara konflik yang secara kreatif dapat diturunkan kembali dari tangga eskalasi. Jadi resolusi konflik menurut Pruit dan Rubin adalah strategi-strategi penyelesaian konflik untuk memecahkan kemandekan dan deskalasi (Pruit dan Rubin 2004:414).

Di samping itu menurut Miall, resolusi konflik adalah usaha menghentikan konflik dengan cara-cara analitis dan masuk ke akar permasalahan. Resolusi konflik berarti menyelesaikan konflik dengan memecahkan akar-akar dasar konflik sehingga hubungan tidak lagi ada kekerasan, sikap pihak-pihak yang bertikai satu sama lain tidak lagi bermusuhan, dan struktur konflik telah berubah (Miall 2002:31). Resolusi Konflik di luar Peradilan

Penyelesaian konflik diluar peradilan (non-litigasi) atau Alternative Dispute Resolution (ADR) merupakan pendekatan penyelesaian konflik yang mengedepankan penyelesaian konflik di luar peradilan formal (Saptomo, 1994:510). Proses penyelesaian konflik non-litigasi dapat diselesaikan dengan cara musyawarah mufakat karena masyrakat dipandang aktif memilih dan menentukan hukumnya sendiri. Hukum yang dimaksud bukan berarti hukum tertulis sebagaimana yang tertulis dalam peradilan formal, akan tetapi mencakup prosedur, 
substansi, nilai-nilai budaya maupun prinsip-prinsip hukum. Menurut Andiko (2014: 16), dalam sistem hukum Indonesia, ADR diartikan sebagai Alternatif penyelesaian sengketa yang merupakan lembaga penyelesaian sengketa atau beda pendapat melalui prosedur yang disepakati para pihak, yakni penyelesaian diluar pengadilan dengan cara konsultasi, negosiasi, mediasi, konsiliasi, atau penilaian ahli.

Intervensi Pihak Ketiga

Menurut Soerjono Soekanto (1998:241), dalam menyelesaikan konflik ada model intervensi pihak ketiga. Dalam model ini ada beberapa bentuk, yakni coercion, arbitrasi, dan mediasi.

Menurut Johal Galtung (1999:228), intervensi yang dilakukan oleh pihak ketiga terhadap pihak yang berkonflik adalah sebagai komunikasi. Intervensi dari pihak luar hadir untuk menhentikan penderitaan lebih jauh dan kehancuran material dan non material, jika mungkin untuk sampai pada solusi, yang berarti formasi yang dapat diterima dan berkelanjutan.

Menurut Afrizal (2015:143) keberhasilan pihak ketiga dalam menyelesaikan konflik tidak hanya bergantung pada kemampuan pihak ketiga tetapi juga konteks dari konflik yang diselesaikan. Konteks itu adalah peraturan perundang-undangan termasuk hukum adat. Lebih lanjut Afrizal menyatakan, Keberhasilan intervensi pihak ketiga dalam menyelesaikan konflik dipengaruhi oleh tindakan-tindakan pihak ketiga dan konteks struktural dari konflik.

\section{Tinjauan Sosiologis}

Untuk mencapai tujuan dalam penelitian ini peneliti menggunakan teori strukturasi. Teori strukturasi merupakan teori yang dikembangkan oleh Anthony Giddens. Dalam teori ini, Giddens menganjurkan untuk melihat hubungan antara pelaku (tindakan) dan struktur secara dualitas. Keduanya tidak dapat dipisahkan, melainkan merupakan dua sisi dari satu mata uang. Giddens mengatakan setiap riset dalam ilmu sosial menyangkut penghubungan tindakan (sering kali disinonimkan dengan agen) dengan struktur (Ritzer dan Douglas 2004: 507).

Teori strukturasi yang dijelaskan Giddens memfokuskan perhatian pada socialpracties, yang menghubungkan antara sosiologi makro dan sosiologi mikro, melalui hubungan antara agen dan struktur. Agen dan struktur ada dalam hubungan dualitas dan saling mempengaruhi, dan bukan dualism. Semua social action melibatkan social aktor, dan keduanya begitu erat dalam aktivitas atas practice manusia secara berkelanjutan (Pitana, 2005:26). Agen dan struktur yang dimaksud disini adalah staf DPMN Kabupaten Sijunjung, serta permendagri nomor 1 tahun 2017 sebagai struktur.

Bila teori ini dikaitkan dengan permasalahan penelitian, maka dapat dijelaskan bahwa DPMN sebagai instansi yang memiliki agen dan struktur, menyelesaikan konflik Tanah Ulayat KAN Nagari Limo Koto dengan Pemerintah Nagari Persiapan Padang Laweh.

\section{B.METODE PENELITIAN}

\section{Pendekatan dan Tipe Penelitian}

Metode yang digunakan dalampenelitian ini adalah metode kualitatif. Penelitian ini mencoba mendeskripsikan bagaimana proses DPMN Kabupaten 
Sijunjung menyelesaikan kasus konflik batas wilayah antara Nagari Persiapan Padang Laweh Selatan dengan Nagari Limo Koto.

Tipe penelitian deskriptif yang dimaksudkan dalam penelitian ini ialah mendeskripsikan suatu fenomena yang berhubungan dengan masalah dan unit yang diteliti. Penggunaan tipe penelitian ini akan memberikan peluang dalam mengumpulkan data-data yang bersumber dari wawancara, catatan lapangan, fotofoto, dokumen pribadi dan dokumen resmi guna menggambarkan subjek penelitian (Moleong, 1998: 6).

\section{Informan Penelitian}

Penelitian ini menggunakan informan sebagai subjek penelitian yaitu orangorang yang dipilih sesuai dengan kepentingan permasalahan dan tujuan penelitian.

Terdapat dua kategori informan menurut Afrizal (2014:139), diantaranya :

1. Informan Pelaku, yaitu informan yang memberikan keterangan tentang dirinya, tentang perbuatannya, tentang pikirannya, tentang interpretasinya (maknanya) atau tentang pengetahuannya. Mereka adalah subjek dari penelitian itu sendiri. Yang akan menjadi informan pelaku adalah stafDPMN Kab. Sijunjung, serta ninik mamak Nagari Limo Koto dan staf pemerintahan Nagari Persiapan Padang Laweh Selatan.

2. Informan Pengamat, yaitu informan yang memberikan informasi tentang orang lain atau suatu kejadian atau suatu hal kepada peneliti. Informan kategori ini dapat orang yang tidak diteliti dengan kata lain orang lain yang mengetahui orang yang kita teliti atau agen kejadian yang diteliti. Mereka disebut sebagai saksi suatu kejadian atau pengamat lokal. Dalam berbagai literatur mereka ini disebut pula sebagai informan kunci. Dalam penelitian ini informan pengamatnya adalah saksi-saksi yang hadir dalam rapat, dan pernah terlibat dalam proses pemekaran Nagari Persiapan Padang Laweh Selatan.

\section{TEMUAN DAN PEMBAHASAN}

Peran Pemerintah Daerah Menyelesaikan Konflik Pemekaran Nagari Antara Nagari Padang Laweh Selatan dengan Nagari Limo Koto Kecamatan Koto VII Kabupaten Sijunjung.

\section{Kronologi Konflik Tanah Ulayat KAN Nagari Limo Koto dengan Nagari Persiapan Padang Laweh Selatan}

Nagari Persiapan Padang Laweh Selatan merupakan salah satu nagari baru yang saat ini statusnya masih Nagari Persiapan. Nagari Persiapan Padang Laweh Selatan merupakan Nagari persiapan yang dimekarkan dari Nagari Padang Laweh. Saat ini, Pemekaran Nagari Persiapan Padang Laweh Selatan diusulkan oleh komunitas Jorong Sungai Gemuruh dan Jorong Ranah Sigading, kedua jorong tersebut pada saat itu merupakan bagian dari Nagari Padang Laweh. Usulan tersebut didasari pada kesepakatan antara 6 orang urang tuo, 10 orang ninik mamak, 3 orang dubalang, 20 orang pemuda dan masyarakat, 15 orang panitia, 3 orang bongku, 2 orang ulama dan 1 orang bundo kandung.

Pemekaran Nagari Persiapan Padang Laweh Selatan dimulai pada tanggal 18 Agustus 2010, adanya proposal usulan pemekaran nagari dan pengukuhan Jorong Sungai Gemuruh dan Ranah Sigading menjadi Nagari definitif Padang Laweh Selatan yang ditindak lanjuti dengan surat camat Koto VII. 
Terdapat beberapa hambatan dalam proses pemekaran Nagari Persiapan Padang Laweh Selatan. Salah satunya adalah dampak pemberhentian sementara proses pemekaran nagari akibat surat dari Gubernur Sumatera Barat Nomor 140/565/Pem-2012 perihal moratorium Pemekaran Nagari, Desa dan Kelurahan. Pemberhentian proses pemekaran sementara ini terjadi selama 2 tahun, dimulai tahun 2012 sampai tahun 2014. Moratorium Pemekaran Nagari tahun 2012 tersebut menghambat proses pemekaran dikarenakan adanya pembahasan tentang UndangUndang No. 32 tahun 2004 Tentang Desa oleh DPR. Oleh sebab itu, semua proses pemekaran terkait Nagari, Desa dan Kelurahan dihentikan sementara sampai disahkannya Undang-undang tersebut.

Setelah dilanjutkan kembali proses pemekaran Nagari Persiapan Padang Laweh Selatan pasca Moratorium pemekaran Nagari oleh Gubernur Sumatera, sekitar bulan Juli 2014 terdapat protes pemekaran Nagari Persiapan Padang Laweh Selatan oleh Ninik Mamak Nagari Limo Koto. Protes yang dilakukan oleh Ninik Mamak Nagari Limo Koto pada saat itu belum sampai ke tahap gugatan, hanya sebatas penyampaian protes kepada Wali Nagari bahwa Pemekaran Nagari Persiapan Padang Laweh Selatan tidak boleh dilaksanakan, karena wilayah Nagari Persiapan Padang Laweh Selatan terdapat Tanah Ulayat milik Ninik Mamak Nagari Limo Koto.

Protes pemekaran yang dilakukan oleh Ninik Mamak Nagari Limo Koto Kepada Pemerintah Nagari Persiapan Padang Laweh Selatan terjadi saat proses pemekaran pada tahap Pemerintah Daerah Kabupaten Sijunjung melakukan pengkajian Nagari Pemakaran. Protes tersebut dilakukan karena Pemerintah Nagari Persiapan Padang Laweh Selatan tidak memberi tahu diadakannya Pemekaran Nagari Persiapan Padang Laweh Selatan kepada Ninik Mamak Nagari Limo Koto sebagai pemilik tanah ulayat. Oleh sebab itu, Ninik Mamak Nagari Persiapan Padang Laweh Selatan melakukan protes.

\section{Protes Pemekaran dari Ninik Mamak Limo Koto}

Pada tahun 2014, setelah berakhirnya Moratorium Pemberhentian sementara pemekaran Nagari oleh Kementrian Dalam Negeri, dilakukan pengkajian Pemekaran Nagari Persiapan Padang Laweh Selatan oleh Pemerintah Kabupaten Sijunjung. Ketika proses pengkajian pemekaran berlangsung, ninik mamak Nagari Limo Koto memprotes pemekaran Nagari Persiapan Padang Laweh Selatan. Protes tersebut berbentuk penolakan diadakannya pemekaran Nagari Persiapan Padang Laweh Selatan tanpa dikeluarkannya surat gugatan. Penolakan tersebut di sampaikan kepada Pemerintah Nagari Persiapan Padang Laweh Selatan oleh Ninik Mamak Nagari Limo Koto secara lisan. Protes didasari oleh tidak diberitahukannya Ninik mamak Nagari Limo Koto oleh Pemerintah Nagari Persiapan Padang Laweh Selatan perihal dilakukannya pemekaran Nagari, padahal tanah ulayat ninik Mamak Nagari Limo Koto berada di wilayah Administrasi Nagari Persiapan Padang Laweh Selatan.

Sebelum terjadinya pemekaran, Nagari Limo Koto tidak ada mempermasalahkan keberadaan tanah ulayat di Nagari Padang Laweh yang sekarang sudah menjadi bagian Nagari Padang Laweh Selatan. karena berdasarkan sejarahnya, Nagari Limo Koto hanya memberikan tanah tersebut kepada Nagari Padang Laweh tidak untuk di bagi atau dijadikan Nagari baru. 
Selain itu, akan dibangunnya pertembangan minyak bumi di Kabupaten Sijunjung, juga menjadi ketakutan bagi Nagari Limo Koto apabila nantinya urusan tanah terkait akan dibangunnya tambang minyak tersebut tidak mengikutsertakan ninik mamak Nagari Limo Koto sebagai pemilik ulayat.

Akan dibangunnya tambang minyak tersebut, membuat KAN Nagari Limo Koto ingin mempertegas mengenai kepemilikan tanah ulayat di Nagari Padang Laweh Selatan. hal tersebut merupakan alasan ekonomi yang mendasari penolakan KAN Nagari Limo Koto terhadap pemekaran Nagari persiapan Padang Laweh Selatan.

Dalam protes yang dilakukan oleh Ninik Mamak Nagari Limo Koto, Nagari Persiapan Padang Laweh Selatan merespon untuk menyelesaikan permasalahan ninik mamak Nagari Limo Koto, walaupun didalam syarat pemekaran tersebut tidak disebutkan untuk memberi tahu pemilik tanah ulayat perihal pemekaran nagari. Protes tanpa surat gugatan ini berlangsung lebih dari tiga tahun, dimulai bulan juli tahun 2014 sampai 13 November 2017.

Pada tanggal 13 November 2017 pemekaran Nagari Persiapan Padang Laweh Selatan diprotes oleh ketua KAN Nagari Limo Koto, yaitu DT. Samburapi melalui surat gugatan pemekaran. Ketua KAN Nagari Limo Koto tersebut melakukan penolakan melalui surat yang dikirimkan kepada Bupati Kabupaten Sijunjung nomor : 31/KAN-LK/XII-2017 perihal Menolak pemekaran Nagari Persiapan Padang Laweh Selatan. Alasan Ketua KAN Nagari Limo Koto memprotes pemekaran tersebut dikarenakan tidak adanya pemberitahuan atau Raso Pareso Nagari Persiapan Padang Laweh Selatan kepada Ninik Mamak Limo Koto sebagai salah satu Pemilik tanah Ulayat di wilayah Padang Laweh Selatan mengenai akan diadakannya pemekaran,

KAN Nagari Limo Koto yang memprotes pemekaran berasal dari perwakilan ninik mamak dan pemilik Tanah Ulayat yang menolak secara kelembagaan. Pihakpihak yang menolak adalah DT. Samburapi, Dt. Rajo Polowan, S.DT. Paduko Malin, A.DT. Paduko Nan Panjang, H.WA.DT. Bijo Dirajo

Dalam surat Penolakan KAN Nagari Limo Koto terhadap Pemerintahan Nagari Persiapan Padang Laweh Selatan, disampaikan 5 hal sebagai berikut:

1. Bahwa sebagian besar wilayah kerja pemerintahan Nagari persiapan Padang Laweh Selatan itu berada dalam tanah ulayat ninik mamak Nagari Limo Koto.

2. Pada dasarnya ninik mamak tidak keberatan atas pemekaran nagari tersebut tetapi ulayat kaum ninik mamak Nagari Limo Koto tidak dimasukkan kedalam wilayah kerja Nagari persiapan Padang Laweh Selatan karena kami Nagari Limo Koto tidak seadat dan sepusako dengan Nagari Padang Laweh.

3. Jika ingin mendirikan Nagari Persiapan Padang Laweh Selatan seharusnya namanya ditukar menjadi Nagari Limo Koto Timur karena wilayah kerja sebahagian besar adalah ulayat ninik mamak Nagari Limo Koto.

4. Pembuatan Ranperda Nagari Persiapan Padang Laweh Selatan yang diajukan oleh Pemda Kabupaten Sijunjung kepada DPRD Kabupaten Sijunjung tersebut tidaklah sesuai dengan Undang-Undang karena tidak ada pengkajian secara akademis.

5. Ranperda Nagari persiapan Padang Laweh Selatan yang diajukan Bupati Sijunjung kepada DPRD Kabupaten Sijunjung itu tidak ada di sosialisasikan kepada ninik mamak Nagari Limo Koto selaku yang punya ulayat padahal 
wilayah kerja Pemerintahannya berada didalam ulayat ninik mamak Nagari Limo Koto.

Dari penjelasan diatas, ninik mamak Nagari Limo Koto sebagai pemilik tanah ulayat merasa tidak diajak dalam pemekaran Nagari Persiapan Padang Laweh Selatan sehingga melakukan penolakan terhadap pemekaran tersebut. Ketakutan Nagari Limo Koto, jika pemekaran tidak melibatkan mereka, nanti mereka akan mengalami kerugian apabila tanah ulayat tersebut memiliki potensi.

Tanah ulayat yang menjadi objek yang disengketakan, terdapat di Jorong Sungai Gemuruh, Jorong Pasar Gambo, dan Jorong Ranah Sigading. Diatas tanah yang disengketakan itu terdapat pemukiman penduduk, dimana pemukiman tersebut sudah dihuni oleh masyarakat Nagari Padang laweh. Selain itu tanah ulayat tersebut juga terdapat ladang, sawah dan juga pasar. Tanah ulayat yang disengketakan tersebut merupakan tanah milik Dt. Paduko nan panjang dari suku caniago, dan Dt. Bijo Dirajo dari suku Patopang.

Sebelum terjadinya konflik tanah ulayat antara Nagari Persiapan Padang Laweh Selatan dengan Nagari Limo Koto, hubungan kedua nagari berlangsung dengan baik, tidak ada masalah yang terjadi. Berdasarkan sejarahnya, keberadaan tanah ulayat Nagari Limo Koto di Nagari Padang Laweh, dahulu Nagari Padang Laweh membantu Nagari Limo Koto perang dalam perebutan wilayah dengan Nagari Padang Sibusuk. Nagari Limo Koto berhasil menang dalam peperangan tersebut. Sebagai bentuk terima kasih, Nagari Limo Koto memberikan tanah kepada Nagari Padang Laweh untuk ditempati. Selain itu, dahulu ninik mamak Nagari Limo Koto juga pernah menjual tanah ke masyarakat Padang laweh. Oleh masyarakat Padang Laweh disertifikatkan dan dimasukan kedalam Administrasi Nagari Padang Laweh. Selain itu, hubungan kedua nagari selama ini juga baik, kedua nagari saling membantu dalam kegiatan ekonomi, seperti masyarakat Padang laweh menyadap getah karet ke Nagari Limo Koto atau sebaliknya, dan juga masyarakat Limo Koto banyak yang mengambil pasir ke Nagari Padang Laweh.

\section{Respon Pemerintah Nagari Persiapan Padang Laweh Selatan terhadap Protes}

Konflik yang terjadi semenjak tahun 2014 ini, direspon oleh Pemerintah Nagari Persiapan Padang Laweh Selatan untuk diselesaikan. Dibuktikan dengan diundangnya ninik mamak Nagari Limo Koto untuk melakukan pembicaraan di kantor Wali Nagari Persiapan Padang Laweh Selatan sekitar bulan November 2014. Pertemuan kedua di adakan di Kantor Camat Koto VII, beberapa hari setelah dikirimnya surat Gugatan protes pemekaran oleh KAN Nagari Limo Koto kepada Bupati Sijunjung.

Diluar pertemuan dengan KAN Nagari Limo Koto tersebut, Nagari Persiapan Padang Laweh Selatan juga meminta bantuan kepada Dt. Rangkayo Putiah untuk membantu menyelesaikan Konflik dengan KAN Nagari Limo Koto tersebut.

Dibantu olah DT. Rangkayo Putiah tersebut, akhirnya Ranperda Nagari Persiapan Padang Laweh Selatan dilanjutkan proses perumusannya oleh DPMN dengan melibatkan kedua belah pihak yang berkonflik.

\section{Penyelesaian Konflik oleh Kedua Belah Pihak}

Protes oleh ninik Mamak Nagari Limo Koto semenjak bulan Juli 2014 sampai dikirimnya surat penolakan pemekaran Nagari Persiapan Padang Laweh Selatan tanggal 13 November 2017 tidak menemukan kesepakatan antara kedua belah 
pihak. Selama konflik berlangsung, dilakukan pertemuan sebanyak dua kali antara kedua belah pihak.

\section{Mengkonfirmasi Alasan Tidak Menginformasikan Pemekaran Kepada KAN Nagari Limo Koto}

Pertemuan pertama antara kedua belah pihak untuk menyelesaikan permasalahan dilakukan sekitar bulan November 2014 di Kantor Wali Nagari Persiapan Padang Laweh Selatan. Dalam pertemuan tersebut Ninik mamak Nagari Limo Koto diundang oleh Pemerintah Nagari Persiapan Padang Laweh Selatan untuk melakukan pembicaraan terkait alasan ninik mamak Nagari Limo Koto Memprotes pemekaran Nagari Persiapan Padang Laweh Selatan. Pada pertemuan tersebut dijelaskan bahwa alasan ninik mamak Nagari Limo Koto memprotes pemekaran karena tidak adanya pemberitahuan dari Nagari Persiapan Padang Laweh Selatan kepada Ninik Mamak Nagari Limo Koto mengenai akan diadakannya pemekaran Nagari. Selain itu, Nagari Persiapan Padang Laweh Selatan juga melakukan konfirmasi terkait tidak diinformasikannya pemekaran Nagari Persiapan Padang Laweh Selatan kepada Ninik Mamak Nagari Limo Koto selaku pemilik ulayat. pada pertemuan tersebut dijelaskan bahwa, alasan Nagari Persiapan Padang Laweh Selatan tidak memberitahu Ninik Mamak Nagari Limo Koto karena dalam persyaratan pemekaran nagari, tidak disebutkan untuk memberitahu pemilik ulayat bahwa akan diadakannya pemekaran nagari.

Ninik Mamak Nagari Limo Koto berpendapat bahwa apapun yang dilakukan di atas tanah ulayat Limo Koto, tentu harus diketahui oleh Ninik Mamak Limo Koto sebagai pemilik ulayat pertemuan pertama tersebut tidak menghasilkan jalan keluar antara kedua belah pihak yang berkonflik.

\section{Melakukan Negosiasi tentang Penyelesaian Konflik}

Setelah surat gugatan Pemekaran Nagari persiapan Padang Laweh Selatan oleh KAN Limo Koto tanggal 13 November 2017, Pertemuan dilakukan kembali antara kedua belah pihak yang berkonflik. Pertemuan dilakukan di Kantor Camat Koto VII beberapa hari setelah Surat KAN Nagari Limo Koto dikirim ke Bupati Kabupaten Sijunjung.

Pada pertemuan kedua belah pihak tersebut, dibahas mengenai tidak dimasukkannya ulayat Nagari Limo Koto ke dalam wilayah Nagari persiapan Padang Laweh Selatan dan usulan penggantian nama Nagari Persiapan Padang Laweh Selatan menjadi Nagari Limo Koto Timur jika tetap ingin memasukkan ulayat Nagari Limo Koto ke dalam wilayah Nagari Persiapan Padang Laweh Selatan. Nagari Persiapan Padang Laweh Selatan memberikan alasan bahwa pemekaran ini hanya secara Administratif pemerintahan, sehingga tidak akan mengganggu status tanah ulayat ninik mamak Nagari Limo Koto, dan penggantian nama menjadi Nagari Limo Koto Timur tidak cocok dikarenakan Nagari Persiapan Padang Laweh Selatan bukanlah Nagari yang dimekarkan dari Nagari Limo Koto melainkan dari Nagari Padang Laweh.

Pertemuan tersebut tidak menghasilkan kesepakatan antara kedua belah pihak yang berkonflik, Pemerintah Nagari Persiapan Padang Laweh Selatan, sebagai Nagari yang ditolak pemekarannya oleh KAN Nagari Limo Koto, mengakui kesalahannya dan meminta maaf karena tidak ada memberitahu KAN Nagari Limo Koto sebagai pemilik tanah ulayat perihal pemekaran Nagari Persiapan Padang Laweh Selatan, tetapi Nagari Persiapan Padang Laweh Selatan tidak mau 
mengganti nama menjadi Nagari Limo Koto Timur, oleh karena itu Ketua KAN Nagari Limo Koto tetap tidak menerima Pemekaran tersebut.

Selama dalam proses penyelesaian, intensitas konflik tidak sampai kearah kekerasan. Dikarenakan permasalahan ini hanya menyangkut kalangan elit dari kedua belah pihak yang berkonflik. Selain itu, masyarakat kedua nagari juga tidak banyak yang mengetahui bahwa ada konflik diantara kedua nagari.

\section{Penyelesaian Konflik oleh Pemerintah Daerah melalui DPMN}

Pada Tanggal 18 November 2017, Dinas Pemberdayaan Masyarkat dan Nagari (DPMN) Kabupaten Sijunjung sebagai Dinas yang membawahi pemekaran Nagari persiapan Nagari Persiapan Padang Laweh Selatan mengundang Ketua KAN Nagari Limo Koto untuk mengklarifikasi isi surat gugatan. Dalam pertemuan tersebut staf DPMN menjelaskan mengenai hubungan antara pemekaran Nagari Persiapan Padang Laweh Selatan dengan keberadaan tanah ulayat Ninik mamak Nagari Limo Koto. Ayu menyampaikan bahwa pemekaran Nagari Persiapan Padang Laweh Selatan ini hanya secara administratif, sehingga tidak mengganggu kepemilikan tanah ulayat yang dimiliki oleh ninik Mamak Nagari Limo Koto. Respon dari Ketua KAN Nagari Limo Koto terhadap penjelasan dari perwakilan DPMN tersebut adalah mereka mengerti pemekaran ini hanya secara administratif, tapi kekhawatirannya jika nanti tanah ulayat mereka terdapat sumberdaya yang menguntungkan, tentu nantinya akan berurusan dengan Nagari Persiapan Padang Laweh Selatan, bukan dengan Nagari Limo Koto sebagai pemilik ulayat. Namun, setelah pertemuan tersebut, pada tanggal 28 November 2017 KAN Limo Koto mengirimkan surat kepada Komnas HAM RI perwakilan Sumatera Barat berisi tuntutan yang sama. Pada tanggal 19 Desember 2017 Komnas HAM RI Perwakilan Sumataera Barat mengirim Surat kepada Bupati Sijunjung terkait penolakan KAN Nagari Limo Koto terkait Pemekaran Nagari Pesiapan Padang Laweh Selatan.

Dalam melakukan penyelesaian konflik antara KAN Nagari Limo Koto dengan pemerintahan Nagari Persiapan Padang Laweh Selatan, DPMN tidak mengalami kesulitan yang membuat masalah tersebut tidak sampai kearah kekerasan. Konflik ini hanya sebatas permasalahan kepentingan antara KAN Limo Koto dengan Pemerintahan Nagari Persiapan Padang Laweh Selatan, dan juga yang terlibat dalam konflik ini adalah para elite dari kedua belah pihak, sehingga memang diusahakan konflik ini tidak diketahui oleh masyarkat umum.

Dalam melakukan penyelesaian konflik tersebut, ada beberapa upaya yang digunakan oleh DPMN, sehingga konflik tersebut dapat terselesaikan. Upaya yang dilakukan tersebut yakni:

\section{Membentuk Tim Pemekaran Menyelesaikan Konflik}

Dalam melekukan proses pemekaran, pemerintah daerah membentuk TIM yang bertugas untuk memekarkan Nagari Persiapan Padang Laweh Selatan. Tim tersebut terdiri dari 2 instansi yang saling bekerja sama, yaitu Dinas Pemberdayaan masyarkat dan Nagari dan Bagian Hukum dan HAM. Tim ini juga membantu menyelesaikan konflik yang terjadi antara KAN Limo Koto dengan Pemerintahan Nagari Persiapan Padang Laweh Selatan. Alasan dari tim pemekaran ini menyelesaikan konflik yang terjadai adalah agar ketika nanti Nagari Persiapan Padang Laweh Selatan telah dimekarkan, tidak ada lagi masalah yang di sangkut pautkan. Oleh sebab itu, konflik antara kedua belah pihak sangat diusahakaan agar dapat terselesaikan. 
Dalam proses pemekaran Nagari Persiapan Padang Laweh Selatan, Tim ini juga bertugas menyelesaikan persoalan terkait gugatan penolakan pemekaran oleh KAN Nagari Limo Koto terhadap Nagari Persiapan Padang Laweh Selatan. Berdasarkan nama-nama yang ada dalam Tim Pemekaran Nagari Persiapan Padang Laweh Selatan, rata-rata semua anggota Tim ikut membantu dalam penyelesaian konflik. Namun yang lebih banyak berperan dalam penyelesaian adalah anggota Tim yang berasal dari DPMN, karena DPMN merupakan dinas yang membawahi langsung persoalan pemekaran Nagari.

\section{Mengundang Kedua Belah Pihak yang Berkonflik Secara Terpisah}

Setelah menerima surat penolakan pemekaran Nagari Persiapan Padang Laweh Selatan dari KAN Nagari Limo Koto, DPMN mengadakan pertemuan dengan kedua belah pihak membahas isi gugatan yang dilayangkan oleh KAN Limo Koto di kantor DPMN. namun setelah dua kali diundang untuk melakukan pembicaraan, kedua belah pihak tidak berhasil dipertemukan.

Pertemuan DPMN dengan kedua belah pihak dilakukan pada waktu yang berbeda, tetapi masih di Kantor DPMN. Tujuan dari pertemuan terpisah dengan KAN Nagari Limo Koto adalah untuk meyakinkan mengenai pemekaran Nagari Persiapan Padang Laweh Selatan ini tidak mengganggu keberadaan tanah ulayat Limo Koto. Pada tanggal 18 November 2017, DPMN mengundang KAN Nagari Limo Koto untuk mengklarifikasi gugatan dari KAN Nagari Limo Koto.

Setelah diklarifikasi kepada Ninik mamak Nagari Limo Koto terkait isi surat gugatan, namun pada tanggal 28 November 2017 ninik mamak Nagari Limo Koto mengirimkan surat gugatan kembali kepada Komnas HAM RI perwakilan Sumatera Barat.

Oleh karena itu, pada tanggal 19 Desember 2017, masuklah surat dari Komnas HAM RI perwakilan Sumatera Barat kepada Bupati Sijunjung dan Ketua DPRD Kabupaten Sijunjung, perihal gugatan KAN nagari Limo Koto terkait penolakan pemekaran Nagari Persiapan Padang Laweh Selatan. pada tanggal 23 Januari 2017, Bupati Sijunjung mengirimkan surat kepada Komnas HAM RI perwakilan Sumatera Barat perihal klarifikasi, sedangkan pertemuan dengan Pemerintah Nagari Persiapan Padang Laweh Selatan dilakukan pada tanggal 19 November 2017 untuk mendiskusikan bagaimana pemekaran Nagari Persiapan Padang Laweh Selatan ini dapat dilanjutkan dengan mencari solusi permasalahan dengan KAN Nagari Limo Koto. Pertemuan dengan Nagari Persiapan Padang Laweh Selatan tersebut mendapatkan hasil bahwa mereka tidak mau mengganti nama menjadi Nagari Limo Koto Timur, dikarenakan Nagari Persiapan Padang Laweh Selatan merupakan pemekaran dari Nagari Padang Laweh.

\section{Mengumpulkan Data mengenai Tanah Ulayat yang Disengketakan}

Dikarenakan klarifikasi yang dilakukan oleh DPMN kepada ninik mamak Limo Koto tidak berhasil, DPMN melakukan pengumpulan data terkait tanah ulayat yang menjadi objek permasalahan kedua belah pihak. Tanah ulayat yang dipermasalahkan oleh KAN Nagari Limo Koto merupakan tanah ulayat yang dimiliki oleh Paduko Nan Panjang dari kaum Caniago dan DT. Bijo Dirajo dari kaum Piliang. Tanah ulayat milik kaum Caniago terletak di Jorong Sungai Gemuruh dan Jorong Pasar Gambok, sedangkan kaum Piliang tanah ulayatnya terdapat di Jorong Ranah Sigading. 
Di Tanah ulayat tersebut terdapat pemukiman yang keseluruahnnya dihuni oleh penduduk Nagari Padang Laweh, selain itu juga terdapat kebun dan sawah yang merupakan juga milik dari masyarakat Nagari Padang Laweh. Selain itu, Data mengenai tanah ulayat Nagari Limo Koto yang dikonflikkan terdapat di halaman 51.

Selain mengumpulkan data terkait tanah ulayat ke pihak Nagari Limo Koto, DPMN juga meminta informasi terkait tanah ulayat ke pihak Nagari Padang Laweh Selatan dan KAN Nagari Padang Laweh. Informasi yang didapat dari pihak Nagari Padang Laweh Selatan dan KAN Nagari Padang Laweh, bahwa pihak Nagari Padang Laweh Selatan dan KAN Nagari Limo Koto mengakui tanah ulayat yang dipermasalahkan oleh KAN Nagari Limo Koto adalah milik KAN Nagari Limo Koto.

Hasil dari data mengenai Tanah Ulayat yang dikonflikkan ini, membuat DPMN mengetahui di wilayah mana saja tanah ulayat tersebut berada beserta pemiliknya, sehingga dengan data tersebjt DPMN juga bisa melakukan pembicaraan dengan pemilik tanah ulayat agar permasalahan ini dapat diselesaikan.

\section{Menelusuri Sejarah Tanah Ulayat}

Selain mencari data mengenai tanah ulayat yang dikonflikkan oleh KAN Nagari Limo Koto, DPMN juga menelusuri sejarah keberadaan tanah ulayat Nagari Limo Koto di Nagari Persiapan Padang Laweh Selatan. Setelah ditelusuri melalui panghulu pucuk Nagari Limo Koto yang tidak terlibat dalam penolakan beserta Ninik mamak Padang Laweh, ternyata Padang Laweh Selatan tidak mempunyai adat salingkung / selingkup nagari, tetapi hanya memiliki adat salingkung / selingkup Koto

Berdasarkan sejarahnya, ternyata keberadaan tanah ulayat Nagar Limo Koto di Nagari Padang Laweh adalah salah satu bentuk imbalan yang diberikan oleh Nagari Limo Koto kepada Nagari Padang Laweh, karena dahulunya Nagari Limo Koto terlibat perang dengan Nagari Padang Sibusuk perihal perebutan tanah. Nagari Limo Koto meminta bantuan kepada rajo Biduo sebagai pemimpin di Padang Laweh berupa anggota masyarkat untuk ikut berperang, oleh karena itu dikirimlah utusan-utusan oleh Rajo Biduo untuk membantu Limo Koto dalam peperangan. Dalam perang tersebut Limo Koto berhasil menang dengan bantuan Padang Laweh. Imbalan yang diberikan oleh Limo Koto adalah tanah yang ditempati oleh masyarakat Padang Laweh.

Dikarenakan pertolongan yang dibeikan oleh Nagari Padang Laweh kepada Nagari Limo Koto, sehingga membuat Nagari Limo Koto memberikan imbalan Kepada Nagari Padang Laweh berupa Tanah untuk ditempati.

Tanah yang ditempati oleh masyarakat Padang Laweh juga merupakan hasil dari penjualan dari Ninik mamak Limo Koto, lama-kelamaan tanah yang dijual yang pada awalnya berlokasi diperbatasan kedua nagari, masuk kedalam wilayah Nagari Padang Laweh. Dikarenakan yang mempunyai tanah tersebut secara pusako rendah adalah masyarakat Padang Laweh, sehingga membuat tanah tersebut masuk kedalam wilayah administrasi Nagari Padang Laweh.

Dalam melaukukan penelusuran sejarah, DPMN juga meminta informasi kepada KAN Nagari Padang Laweh mengenai keberadaan tanah ulayat Nagari Limo Koto di Nagari Padang Laweh. KAN Nagari Padang Laweh mengatakan 
bahwa tanah ulayat tersebut adalah bentuk bermamak kemenakan antara Nagari Limo Koto dengan Nagari Padang Laweh. Selain itu, juga karena posisi Nagari Padang Laweh yang Ketitiran Diujung Telunjuk, membuat warga Nagari Padang Laweh harus mencari tanah untuk dijadikan ladang, termasuk mencari ke Nagari Limo Koto. Oleh karena itu, tanah ulayat Nagari Limo Koto bisa berada di Nagari Padang Laweh.

Dengan ditelusurinya sejarah mengenai keberadaan tanah ulayat Nagari Limo Koto di wilayah Nagari Persiapan Padang Laweh Selatan tersebut, membuat Nagari Persiapan Padang Laweh Selatan menerima apapun keputusan dari DPMN, asalkan mereka tetap dimekarkan. Selain itu, dalam penelusuran sejarah tanah ulayat tersebut, juga membuat DPMN mengetahui ninik mamak yang berpengaruh di Nagari Limo Koto, karena tidak semua ninik mamak Nagari Limo Koto mengetahui sejarah tanah ulayat tersebut.

\section{Menjadikan Elit dari KAN Limo Koto sebagai Mitra dalam Menyelesaikan Konflik}

Dalam melakukan penyelesaian konflik antara KAN Limo Koto dengan Pemerintahan Nagari Persiapan Padang Laweh Selatan, salah satu cara yang dilakukan oleh DPMN adalah menjadikan salah satu ninik mamak Nagari Limo Koto yang memiliki pengaruh terhadap Nagari tersebut sebagai mitra untuk membantu menyelesaikan konflik.. Ninik mamaknya itu adalah Abizar Dt. Rangkayo Putiah, sebagai orang yang dituakan di Nagari Limo Koto, dimana ia merupakan tempat bertanya persoalan adat dan sejarah Nagari Limo Koto

Pada awalnya, Abizar diundang ke DPMN untuk membicarakan persoalan hubungan keberadaan tanah ulayat Nagari Limo Koto dengan Pemekaran Nagari Persiapan Padang Laweh Selatan. setelah itu, Abizar diminta untuk mampu menjelaskan klarifikasi terkait isi surat gugatan kepada Ninik Mamak Limo Koto yang tetap bersikeras menolak pemekaran. Abizar menjelaskan ke ninik mamak Nagari Limo Koto yang menolak pemekaran dengan memberi tahu bahwa pemekaran ini bertujuan baik untuk mensejahterakan masyarakat, dan juga Abizar memberi tahu kepada ninik mamak yang bersikeras menolak pemekaran tetapi tidak memiliki tanah ulayat di Nagari Persiapan Padang Laweh Selatan untuk setuju diadakannya pemekaran. Pada akhirnya, KAN Limo Koto sebagai lembaga yang menolak pemekaran Nagari Persiapan Padang Laweh Selatan setuju dengan pemekaran tersebut secara bersyarat.

\section{Membuat Kesepakatan antara Kedua Belah Pihak melalui Ranperda}

KAN Nagari Limo Koto dalam penyelesaian akhirnya setuju dengan pemekaran Nagari persiapan Padang Laweh Selatan secara bersyarat. KAN Nagari Limo Koto meminta membuat peraturan daerah terkait urusan surat-menurat persoalan tanah harus di tanda tangani oleh KAN Limo Koto, bukan KAN Padang Laweh kepada DPMN. Aturan yang diminta oleh KAN Nagari Limo Koto dan disepakati oleh Nagari Persiapan Padang Laweh Selatan yang terdapat dalam Ranperda Pemekaran Nagari Persiapan Padang Laweh Selatan Pasal 15 sebagai berikut:

1. Nagari yang dibentuk dalam peraturan daerah ini tidak diikuti dengan pembentukan Kerapatan Adat Nagari Baru.

2. Setiap pendaftaran dan pelepasan hak atas tanah yang berada di wilayah administrasi Nagari Persiapan Padang Laweh Selatan harus mendapat persetujuan dari Kerapatan Adat Nagari pemilik ulayat di wilayah tersebut. 
Dibuatnya aturan tersebut, membuat Nagari Persiapan Padang Laweh Selatan tidak memiliki Kerapatan Adat Nagari. Sehingga Nagari Persiapan Padang Laweh Selatan tetap berkoordinasi dengan KAN Nagari Padang Laweh sebagai nagari induk.

Diselesaikannya konflik antara KAN Nagari Limo Koto dengan Nagari Persiapan Padang Laweh Selatan melalui pembauatan kesepakatan dalam Ranperda Nagari Padang Laweh Selatan, menandakan penyelesaian konflik ini hanya bersifaat administratif, bukan substantif, hal tersebut dikarenakan pembuatan Ranperda meruapakan bentuk administrative dalam penyelesaian konflik ini.

\section{Melakukan Desiminasi Ranperda kepada Kedua Belah Pihak}

Dalam pengambilan kesepakatan terkait isi Ranperda, DPMN mengadakan 3 kali rapat pembahasan dan Desiminasi isi Ranperda dengan kedua belah pihak yang berkonflik. Agar isi dari Ranperda ini sesuai dengan kepentingan dari kedua belah pihak. Pada tanggal 2 April 2018, diadakan sosialisasi ranperda Nagari Persiapan Padang Laweh Selatan kepada Ninik Mamak Nagari Limo Koto beserta pemerintahan Nagari Persiapan Padang Laweh Selatan terkait hasil akhir isi Ranperda Nagari Persiapan Padang Laweh Selatan. Tujuan dari Desiminasi tersebut adalah agar tidak terjadi kesalah pahaman.

\section{Faktor yang Memudahkan DPMN dalam Menyelesaikan Konflik}

Faktor yang memudahkan penyelesaian konflik. Faktor tersebut adalah sebagai berikut:

\section{Menjadikan Peraturan-Peraturan yang Digunakan Dalam Proses Pemekaran} Nagari Persiapan Padang Laweh Selatan sebagai Acuan

Dalam keberhasilan menyelesaikan konflik antara Ninik Mamak Nagari Limo Koto dengan Pemerintahan Nagari Persiapan Padang Laweh Selatan, salah satu faktor yang memudahkan DPMN adalah penggunaan peraturan yang digunakan selama proses Pemekaran nagari sebagai acuan. Peraturan-peraturan tersebut digunakan untuk mengklarifikasi hal-hal yang ditolak oleh KAN Nagari Limo Koto terkait Pemekaran Nagari Persiapan Padang Laweh Selatan dan juga untuk membuat kesepakatan antara kedua belah pihak yang berkonflik sehingga konflik dapat diselesaikan. Pertama, Perda Provinsi Sumatera Barat Nomor 6 tahun 2008 tentang tanah ulayat dan pemanfaatannya

Berdasarkan Perda tersebut, DPMN dapat mengklarifikasi penolakan KAN Nagari Limo Koto terkait wilayah kerja Nagari Persiapan Padang Laweh Selatan yang berada di sebagian besar tanah ulayat ninik mamak Nagari Limo Koto.

Kedua, DPMN menggunakan peraturan bupati Sijunjung nomor 7 tahun 2012 pasal 1 tentang pembentukan Nagari persiapan Padang Laweh Selatan Kecamatan Koto VII untuk mengklarifikasi keinginan KAN Nagari Limo Koto untuk mengganti nama Nagari Persiapan Padang Laweh Selatan menjadi Nagari Limo Koto Timur.

Ketiga, tentang penolakan KAN Nagari Limo Koto terhadap pemekaran Nagari Persiapan Padang Laweh Selatan mengenai Pembuatan Ranperda Nagari Persiapan Padang Laweh Selatan yang diajukan oleh Pemda Kabupaten Sijunjung kepada DPRD kabupaten Sijunjung tidak sesuai dengan Undang-undang karena tidak ada pengkajian akademis. DPMN menggunakan Permendagri No 1 Tahun 2017 tentang Penataan Desa dan UU no 6 tahun 2014 tentang desa untuk mengklarifikasi bahwa pemekaran Nagari Persiapan Padang Laweh Selatan telah 
sesuai dengan peraturan yang berlaku. Selain itu, DPMN juga menggunakan surat Gubernur Sumatera Barat no 120/307/Pem-2016 tanggal 20 April 2016 perihal pemekaran Nagari, yang menyatakan bahwa proses Nagari Persiapan Padang Laweh Selatan menjadi nagari defenitif data dilanjutkan dengan penyusunan Ranperda pembentukan nagari tersebut.

Selain penggunaan peraturan untuk mengklarifikasi hal-hal yang dipermasalahkan oleh KAN Nagari Limo Koto, DPMN juga menggunakan Permendagari No 1 Tahun 2017 tentang Penataan Desa sebagai acuan dalam proses penyelesaian Konflik antara kedua nagari. Kesepakatan antara kedua belah pihak yang berkonflik yang dituangkan dalam Ranperda Nagari Persiapan Padang Laweh Selatan juga telah diatur dalam Permendagri No 1 tahun 2017 pasal 70 ayat 4 poin E. Ayat dan poin tersebut merujuk pada pasal 68 ayat 1.Selanjutnya, Pasal 70 ayat 4 poin E menjelaskan mengenai kepentingan masyarakat yang dimaksud dalam pasal 68 ayat 1.

Kemudahan yang diberikan oleh Permendagri no 1 tahun 2017 dalam pembuatan isi Ranperda Pemekaran Nagari, membuat DPMN dapat membuat kesepakatan antara KAN Nagari Limo Koto dengan Pemerintah Nagari Persiapan Padang Laweh Selatan. DPMN menuangkan kesepakatan antara kedua belah pihak dalam Ranperda Nagari Persiapan Padang Laweh Selatan pasal 15. Isi dari Ranperda pasal 15 tersebut menyebutkan bahwa Nagari Persiapan Padang Laweh Selatan tidak boleh membentuk Kerapatan Adat Nagari Baru dan setiap pendaftaran dan pelepasan hak atas tanah yang berada di wilayah Nagari Persiapan Padang Laweh Selatan harus mendapat persetujuan dari KAN pemilik ulayat di wlayah tersebut.

Keberhasilan DPMN dalam menyelesaikan konflik antara KAN Nagari Limo Koto dan Pemerintah Nagari Persiapan Padang Laweh Selatan tidak hanya bergantung pada kemampuan dari agen DPMN saja, namun juga peraturanperaturan yang digunakan dalam penyelesaian konflik tersebut. Jika Permendagari No 1 tahun 2017 tidak mengatur tentang isi Ranperda Nagari pemekaran, maka kesepakatan antara kedua belah pihak sulit dicapai.

Aktor DPMN dan Elit Nagari Limo Koto memahami Pemekaran Nagari Bertujuan untuk Meningkatkan Kesejahteraan Masyarakat

Selesainya konflik antara Ninik Mamak Nagari Limo Koto dengan Pemerintahan Nagari Persiapan Padang Laweh Selatan tidak terlepas dari peran aktor DPMN dan elit Nagari Limo Koto yang membantu menyelesaikan konflik. Elit Nagari Limo Koto memahami tujuan dari pemekaran ini adalah untuk meningkatkan kesejahteraan masyarakat, sehingga ia mampu memberikan pemahaman terkait hubungan keberadaan tanah ulayat Nagari Limo Koto dengan Pemekaran Nagari Persiapan Padang Laweh Selatan kepada ninik mamak Nagari Limo Koto yang melakukan penolakan, dan membuat Pemekaran Nagari Persiapan Padang Laweh Selatan dapat dilanjutkan.

Karena adanya penjelasan dari Abizar dan Tim Pemekaran terkait hubungan keberadaan tanah ulayat Nagari Limo Koto dengan Pemekaran Nagari Persiapan Padang Laweh Selatan, pihak ninik Mamak Nagari Limo Koto serta pemilik ulayat yang pada awalnya menolak pemekaran Nagari Persiapan Padang Laweh Selatan, akhirnya setuju dengan pemekaran tersebut.

Konflik yang Terjadi tidak Rumit 
Salah satu faktor yang memudahkan DPMN dalam menyelesaikan konflik antara Ninik Mamak Nagari Limo Koto dengan Pemerintah Padang laweh Selatan adalah konflik yang terjadi tidak begitu rumit, jadi dapat diselesaikan. Bukti tidak rumitnya konflik ini adalah tidak adanya perbedaan sudut pandang dari kedua belah pihak terkait tanah ulayat yang di konflikkan, seperti Pemerintahan Nagari Persiapan Padang Laweh Selatan mengakui keberadaan Tanah ulayat Nagari Limo Koto.

Pengakuan yang diberikan oleh Nagari Persiapan Padang Laweh Selatan terkait tanah ulayat Nagari Limo Koto membuat DPMN serta Tim Pemekaran bisa memfokuskan penyelesain pada pihak Nagari Limo Koto saja, karena apabila kedua belah pihak bersikeras untuk mempertahankan asumsi masing-masing, maka penyelesaian akan sulit dicapai.

\section{KESIMPULAN}

Dalam penyelesaian konflik anatra Nagari Persiapan Padang Laweh Selatan dengan Nagari Limo Koto dapat berhasil dilakukan sehingga dikeluarkannya Ranperda Nagari Persiapan Padang Laweh Selatan. Dalam proses penyelesaian konflik tersebut, DPMN sebagai pihak ketiga mengalami kesulitan dalam mempertemukan kedua belah pihak yang berkonflik. Konflik tersebut disebabkan oleh perbedaan yang mendasar antara Hukum Adat dengan Aturan Negara secara administratif sebagai sebuah struktur yang mengekang (constraining). Ide-ide tentang bahwa pemekaran Nagari Padang Laweh Selatan tidak berdampak pada kepemilikan tanah ulayat Nagari Limo Koto sulit dipahami karena menggunakan cara pandang Hukum Adat. Hukum Adat memandang tanah ulayat pengaturannya dilakukan oleh ninik mamak KAN dan Pemerintah Nagari dengan adat minangkabau. Kesulitan dalam melakukan pertemuan dan adanya perbedaan mendasar antara Hukum Adat dengan Aturan Negara Secara Administratif adalah sebuah struktur yang mengekang (constraining) bagi terjadinya praktik sosial, karena kedua belah belum menemukan kesepakatan terkait konflik tanah ulayat. Struktur yang mengekang (constraining) tersebut tidak sepenuhnya membatasi pelaksanaan penyelesaian konflik tersebut.

Selain itu, nilai dan norma yang berlaku di masyarakat Kecamatan Koto VII Kabupaten Sijunjung juga menjadi struktur constraining dalm penyelesaian konflik antara Nagari Persiapan Padang Laweh Selatan dengan Nagari Limo Koto. Di Kecamatan Koto VII, terdapat tujuh jumlah koto sebagai kaum yang memiliki Koto VII. Ketujuh Koto tersebut harus didahulukan selangkah dan ditinggikan seranting dari pada selain ketujuh koto tersebut. Ketujuh koto tersebut adalah lima koto terdapat di Nagari Limo Koto, satu di Nagari Tanjung dan satu di Nagari Palaluar, sedangkan nagari yang tidak termasuk kedalam ketujuh koto tersebut adalah Nagari Padang Laweh, Nagari Padang Laweh Selatan, Nagari Guguk, dan Nagari Bukit Bual. Konflik yang terjadi antara Nagari Persiapan Padang Laweh Selatan dengan Nagari Limo Koto, disebabkan oleh Nagari Persiapan Padang Laweh Selatan tidak memberi tahu Nagari Limo Koto sebagai pemilik ulayat dan yang ditinggikan seranting di Kecamatan Koto VII mengenai akan diadakannya pemekaran nagari. Sedangkan dalam tatanan nilai dan norma yang berlaku pada masyarakat di Kecamatan Koto VII bahwa Nagari Limo Koto merupakan salah satu pemilik tanah ualyat di Kecamatan Koto VII. 


\section{E. UCAPAN TERIMAKASIH}

Penulis mengucapkan terimakasih kepada seluruh informan yang telah bersedia mengalokasikan waktunya selama proses penelitian. Penulis juga mengucapkan ribuan terimakasih kepada para dosen pembimbing yang telah mengarahkan dan menjadi mentor selama pelaksanaan penelitian ini.

\section{DAFTAR PUSTAKA}

\section{Buku:}

Afrizal. 2014. Metode Penelitian Kualitatif : Sebuah Upaya mendukung Penggunaan Penelitian Kualitatf Dalam Berbagai Disiplin Ilmu.. Jakarta: Raja Grofindo Persada.

Afrizal. 2018. Sosiologi Konflik: Pola, Penyebab, dan Mitigasi Konflik Agraria Struktural Di Indonesia. Sidoarjo: Indomedia Pustaka.

Andiko, Harry Oktavian. 2014. Negosiasi efektif Untuk Konflik Sumberdaya Alam. Penerbit Scale Up.

Bungin, Burhan. 2001. Metodologi Penelitian Kualitatif Komunikasi, Ekonomi dan Kebijakan Publik serta Ilmu-ilmu Sosial Lainnya. Jakarta: PT Raja Grafindo Persada.

Fisher. Simon. 2000. Mengelola Konflik: Keterampilan dan strategi Untuk Bertindak. Jakarta: The British Council, Indonesia.

Galtung, Johan. 1999. Studi Perdamaian: Perdamaian dan Konflik Pembangunan dan Peradaban.

Giddens, Anthony. 2010. Teori Strukturasi: Dasar-dasar Pembentuka Struktur Sosial Masyarakat. Yogyakarta: Pustaka Belajar.

Hardiansyah. 2011. Kualitas Pelayan Publik. Yogyakarta: Gava Media.

Miall, Hugh. Oliver Rams botham dan Tom Woodhouse. 2002. Resolusi Damai Konflik Kontemporer. Jakarta: PT. Raja Indo Persada.

Moleong. Lexy. 2004. Penelitian Kualitatif Edisi Revisi. Penerbit Rosda.

Mulyana, Deddy. 2004. Metodologi Penelitian Kualitatif: Paradigma Baru Ilmu Komunikasi dan Ilmu Sosial lainnya. Bandung: Remaja Rosda Karya.

Pitana, I Gede. 2005. Sosiologi Pariwisata. Yogyakarta: CV. Andi Offset.

Poloma, M. Margaret. 2010. Sosiologi Kontemporer. Jakarta: PT. Raja Grafindo Persada.

Pruit, G Dean dan Rubin,Z Jeffrey. 2004. Teori Konflik Sosial.Yogyakarta: Pustaka Belajar.

Ritzer, George. 2003. Sosiologi Ilmu Pengetahuan Berparadigma Ganda. Jakarta: PT. Raja Grafindo Persada.

Ritzer, George dan Douglas J. Goodman. 2004. Teori Sosiologi Modern. Jakarta: Raja Grafindo Persada.

Saptomo, Ade. 1994. Proses penyelesaian Sengketa tanah Di Minangkabau,Laporan Penelitian Proyek SPP/DDP Unand Fak. Hukum.

Soekanto, Soerjono. 1990. Sosiologi suatu pengantar. Jakarta: Raja WaliPers.

Susan, Novri. 2010. Sosiologi Konflik \& Isu-isu Konflik Kontemporer. Jakarta: Kencana. 


\section{Skripsi/Tesis/Disertasi:}

Dingin, Mora. 2013. "Solusi Konflik Kehutanan Dan Rasionalitas Masyarakat Hukum adat": Tesis Jurusan Sosiologi FISIP Universitas Andalas.

Susanto, Hariadi. 2007. "Konflik Batas wilayah Kabupaten Siak dengan Kabupaten Rokan Penyebab dan Resolusi". Skripsi Jurusan Sosiologi FISIP Universitas Andalas.

Roza, Novia. 2011. "Penyebab Konflik Antara Warga Saniang Baka dengan Warga Muaro Pingai Kabupaten Solok". Skripsi Jurusan Sosiologi FISIP Universitas Andalas.

Putri, Zeni Eka. 2012. : "Resolusi Konflik Pembangunan Tower SUTT12 dan 13 antara Warga Padang Besidengan PT PLN Padang". Skripsi Jurusan Sosiologi FISIP Universitas Andalas.

Rahmadani, Sri. 2012. "Peran LSM Q-BAR dalam Resolusi Konflik Tapal Batas Antara Nagari Sumpur dengan Nagari Bungo Tanjuang, Kab. Tanah Datar". Skripsi Jurusan Sosiologi FISIP Universitas Andalas.

Widiyantoro, Rahman. 2016 : "Penyelesaian Persoalan Batas Daerah antara Kabupaten Gunung Kidul dengan Kabupaten Bantul". Skripsi Fakultas Syari'ah dan Hukum Universitas Sunan Kalijaga Yogyakarta.

\section{Laporan Penelitian/Makalah/Jurnal:}

Afrizal. 2015. "Third-Party Intervention In Terminating Oil Palm Plantation Conflicts in Indonesia: A Structural Analysis". Sojourn: Journal Of Social Issues in Southeast Asia Vol. 30, No. 1.

Afrizal. 2013. "Konflik Sumberdaya Alam dan Kapasitas Sosial". APSSI: Kecerdasaan Sosial Mengelola Konflik Seri Sumberdaya Alam. Penerbit: Unversitas Sriwijaya Palembang.

Hasanuddin, Sultan. 2013. “Upaya Pemerintah Kecamatan dalam menyelesaikan konflik perbatasan Desa Di Kutai Kartanegara : studi kasus Desa Badak Baru dengan Desa Batu-Batu".

\section{Peraturan}

UU Nomor 32 tahun 2004 Tentang Pemerintah Daerah.

UU Nomor 6 Tahun 2014 Tentang Penataan Desa.

Permendagri Republik Indonesia Nomor 28 Tahun 2006 Tentang Pembentukan, Penghapusan, Penggabungan Desa dan Perubahan Status.

Permendagri Republik Indonesia Nomor 1 Tahun 20117 Tentang Penataan Desa.

Perda Provinsi Sumatera Barat Nomor 6 Tahun 2008 Tentang Tanah Ulayat.

Peraturan Bupati Sijunjung Nomor 7 Tahun 2012 Tentang Pembentukan Nagari Persiapan Padang Laweh Selatan.

Peraturan Bupati Sijunjung Nomor 48 Tahun 2016 tentang Kedudukan, Susunan

Organisasi, Tugas dan Fungsi serta Tata Kerja pada Dinas Pemberdayaan Masyarakat dan Nagari.

Rancangan Peraturan Daerah Nagari Persiapan Padang Laweh Selatan tahun 2018. 